\title{
Altered Mercury Transport in a Mutant of Pseudomonas fluorescens B69
}

\author{
By TAMAR BARKAY† AND RITA R. COLWELL* \\ Department of Microbiology, University of Maryland, College Park, Maryland 20742, U.S.A.
}

(Received 30 November 1982; revised 29 March 1983)

\begin{abstract}
A 34 MDal plasmid harboured by Pseudomonas fluorescens B69 carried a gene coding for the mercuric reductase enzyme, thus promoting mercury resistance in the host strain. Mercurysensitive variants were isolated when a hypersensitive, cured derivative of strain B69 was exposed to $10 \mu \mathrm{g}$ mercury (II) $\mathrm{ml}^{-1}$. The alteration in mercury transport appeared to be the result of a mutation, since a transconjugant of the mutant, which carried the mercury-resistance plasmid, showed a reduced rate of mercury volatilization compared to the parental resistant strain. In addition, more mercury was tightly bound to the mutant cells. This phenomenon represents a new aspect of bacterial resistance to mercurials.
\end{abstract}

\section{INTRODUCTION}

The 'classic' mercury resistance mechanism in bacteria is the inducible reduction of ionic mercury $\left(\mathrm{Hg}^{2+}\right)$ to the volatile elemental form $\left(\mathrm{Hg}^{0}\right)$, which leaves the growth medium due to its high vapour pressure, allowing commencement of bacterial growth (Weiss et al., 1978). This activity is conferred by mercuric reductase, a cytoplasmic enzyme (Schottel, 1978). Bacteria which are resistant to, and volatilize mercury from organomercurial compounds, produce an organomercurial lyase in addition to the mercuric reductase (Summers \& Silver, 1978). Both enzymes are encoded by genes carried on plasmids in Escherichia coli, pseudomonads and Staphylococcus aureus. Those plasmids which carry genes for the reductase and lyase are termed 'broad range' mercury-resistance plasmids, whereas plasmids which carry the reductase gene alone are termed 'narrow range' resistance plasmids (Weiss et al., 1978). The mercuric reductase gene (mer $A$ ) is a part of the mer operon, which also includes an inducible transport gene (merT) and is positively regulated by the mer $R$ gene product in the presence of certain mercurial compounds. Mercury transport mediated by merT is detected in cells carrying an inactive mer $A$ gene by hypersensitivity to, and hyperbinding of, mercury, compared with mercury-sensitive cells which do not carry the mer operon (Foster et al., 1979).

Although the volatilization of mercury is the best understood mercury-resistance mechanism (Summers \& Silver, 1978), alternative mechanisms exist. Two such examples of plasmiddetermined resistance are the formation of a complex of inorganic mercury with $\mathrm{H}_{2} \mathrm{~S}$ ( $\mathrm{Pan}-\mathrm{Hou}$ \& Imura, 1981) and the presence of a cell wall barrier to ionic mercury (Pan-Hou et al., 1981). Involvement of host cell functions in the mercury-resistance mechanism was suggested by the observed differences in the degree of resistance to mercury demonstrated by Proteus mirabilis and E. coli, each of which harboured the same mercury-resistance plasmid (Nakahara et al., $1979 a$ ).

Pseudomonas fluorescens B69 is a mercury-resistant bacterium isolated from Chesapeake Bay and identified and classified by Austin et al. (1977). Mercury resistance in this strain was conferred by the reduction of the mercuric ion to the volatile elemental form (Olson et al., 1979), and its extracts contained mercuric reductase activity (S. Silver \& T. Kinscherf, personal

$†$ Present address: Program in Social Ecology, University of California, Irvine, California 92717, U.S.A.

Abbreviation: MIC, minimum inhibitory concentration. 
communication). A 34 MDal plasmid carried by $P$. fluorescens $\mathrm{B} 69$ was tentatively identified as a mercury-resistance plasmid, since its spontaneous curing resulted in loss of resistance to mercury (Olson et al., 1979). In this communication, we describe a mutant derivative of $P$. fuorescens B69 which can grow in elevated concentrations of mercurials after elimination of the mercury-resistance plasmid harboured by the parental strain.

\section{METHODS}

Bacterial growth media. Unless specifically mentioned, all experiments were carried out using Yamada medium (Yamada \& Tonumura, 1972) modified to support growth of marine and estuarine bacteria (Olson et al., 1979).

Resistance to mercurial compounds. Susceptibility to mercuric compounds was determined using the disc diffusion test (Bauer et al., 1966). Exponentially growing cultures (turbidity, $\boldsymbol{A}_{525}=\mathbf{0 . 2}$ ) were spread on a solid medium and a disc (Schleicher \& Schuell, Keene, N.H., U.S.A.) impregnated with the inhibiting compound was placed in the centre of the agar plate after inoculation. Plates were incubated at $25^{\circ} \mathrm{C}$ for $48 \mathrm{~h}$, after which the diameter of the zones of inhibition were determined. Mercury compounds tested included: mercuric chloride (Fisher Scientific Company, Fair Lawn, N.J., U.S.A.), mercuric acetate, sodium ethylmercurithiosalicylate (thimerosal) and $p$-hydroxymercuribenzoate (Sigma); all were dissolved in distilled $\mathrm{H}_{2} \mathrm{O}$. Phenylmercuric acetate and fluorescein mercuric acetate (Sigma) were dissolved in methanol and $0.4 \mathrm{M}-\mathrm{NaOH}$, respectively. A solution ( $\mathrm{M}$ in $\mathrm{H}_{2} \mathrm{O}$ ) of methylmercuric hydroxide was purchased from Alfa Division, Ventron Co. (Danvers, Mass., U.S.A.). Minimal inhibitory concentrations (MICs) of inorganic mercury (as $\mathrm{HgCl}_{2}$ ) were determined by diluting cultures $(1: 100)$ in the exponential phase of growth into a series of tubes containing several concentrations of the test compound. Results, i.e. growth versus no growth, compared with growth in the absence of mercury, were recorded after incubation for $48 \mathrm{~h}$ at $25^{\circ} \mathrm{C}$.

Mercury analysis. Volatilization of mercury was determined as previously described (Olson et al., 1979). Total mercury was determined by direct application of liquid samples into the graphite furnace of an atomic absorption spectrophotometer (Perkin Elmer, model 460). Measurements were carried out under the following conditions: dry cycle for $30 \mathrm{~s}$ at $110^{\circ} \mathrm{C}$; char cycle, $0 \mathrm{~s}$ at $110^{\circ} \mathrm{C}$; atomization, $10 \mathrm{~s}$ at $950^{\circ} \mathrm{C}$. Atomized mercury was measured at $253 \mathrm{~nm}$. The spectrophotometer internal standard system, using three reference points $[\mathrm{S} 1=10, \mathrm{~S} 2=5$ and $\mathrm{S} 3=2.5 \mu \mathrm{g} \mathrm{Hg}\left(\mathrm{as} \mathrm{HgCl}_{2}\right) \mathrm{ml}^{-1}$ ) was employed for calibration.

Construction of transconjugant strains. A $34 \mathrm{MDal}$ plasmid was introduced into the cured strain B69A and the mutant strain B69ARI by conjugation between spontaneous streptomycin-resistant derivatives of these strains, as recipients, and $P$. fluorescens $\mathrm{B} 69$ as donor. Recipients were selected by plating a ten-fold concentrated, lateexponential phase culture on to a medium containing $300 \mu \mathrm{g}$ streptomycin sulphate (Sigma) $\mathrm{ml}^{-1}$. About $10^{3}$ colonies per plate were visible after incubation for $48 \mathrm{~h}$ at $25^{\circ} \mathrm{C}$. Overnight cultures of the donor, strain $\mathrm{B} 69$, and recipients, either B69A or B69AR1, were diluted 1:50 into fresh broth and incubated, with shaking, at $25^{\circ} \mathrm{C}$ till a turbidity of $A_{525}=0.5$ was reached. Mating mixtures, consisting of $0.95 \mathrm{ml}$ of diluted $(1: 25)$ recipient suspensions and $0.05 \mathrm{ml}$ of similarly diluted donor suspension were prepared and incubated at $25^{\circ} \mathrm{C}$ with slow shaking, at 50 r.p.m. on a rotary shaker. Matings were halted after $2 \mathrm{~h}$ by diluting and plating the mating mixtures. Transconjugants were selected on a solid medium containing $300 \mu \mathrm{g}$ streptomycin sulphate $\mathrm{ml}^{-1}$ and $15 \mu \mathrm{g} \mathrm{Hg}$ (as $\mathrm{HgCl}_{2}$ ) $\mathrm{ml}^{-1}$. Donor cells were enumerated as previously described (Olson et al., 1979) on a solid medium containing only $10 \mu \mathrm{g} \mathrm{Hg}$ (as $\mathrm{HgCl}_{2}$ ) ml-1 as the selective agent. The plates were incubated for $48 \mathrm{~h}$ at $25^{\circ} \mathrm{C}$. Efficiency of conjugation was found to be $1.5 \times 10^{-4}$ transconjugants per donor cell. Controls, consisting of donor and recipient, were treated identically and did not yield any streptomycin/mercury-resistant derivatives.

Purified clones of transconjugants were designated $\mathrm{B} 69 \mathrm{~A}^{*}$ and B69AR $1^{*}$ for the cured and mutant strains, respectively. The physical presence of a $34 \mathrm{MDal}$ plasmid in DNA preparations from the two transconjugants was detected by agarose gel $(0.8 \%)$ electrophoresis (Olson et al., 1979).

Cell-associated mercury determinations. The proportion of cell-associated mercury, as a percentage of the total mercury, was determined for cultures at the end of the exponential growth phase. Samples for the determination of total mercury were withdrawn prior to separation of cells from the growth medium. Cells were spun down $(8000 \mathrm{~g}$, $15 \mathrm{~min}, 5^{\circ} \mathrm{C}$ ) and the supernatant removed. The pellet was rinsed once and then resuspended in an equal volume of fresh broth. The amounts of mercury in each one of the fractions was determined as described above. Cell rupture and separation of cell walls was carried out as described by Work (1971).

\section{RESULTS}

\section{Isolation of mercury-sensitive mutants}

Pseudomonas fluorescens B69A is a mercury-hypersensitive strain, obtained when the mercury-resistant strain B69 is cured of a $34 \mathrm{MDal}$ plasmid (Olson et al., 1979). The presence of mutant derivatives, less susceptible to mercury than the hypersensitive B69A, was suggested by 
Table 1. Resistance of P. fluorescens strains B69, B69A and B69ARI to mercury compounds

\begin{tabular}{lrcc} 
& \multicolumn{3}{c}{ Zone of inhibition* } \\
\cline { 2 - 4 } \multicolumn{1}{c}{ Compound } & B69 & B69A & B69AR1 \\
Mercuric chloride & 0 & 35 & 23 \\
Mercuric acetate & 14 & 36 & 26 \\
Sodium ethylmercurithiosalicylate & 36 & 34 & 34 \\
$p$-Hydroxymercuribenzoate & 0 & 25 & 0 \\
Phenylmercuric acetate & 24 & 23 & 24 \\
Fluorescein mercuric acetate & 0 & 31 & 24 \\
Methylmercuric hydroxide & 40 & 39 & 49
\end{tabular}

\footnotetext{
* The zone of inhibition is the diameter $(\mathrm{mm})$ around discs impregnated with $50 \mu \mathrm{g}$ of the indicated compound. Values are the mean of duplicate determinations.
}

two observations. Firstly, delayed growth (with a lag period of $3 \mathrm{~d}$ ) was observed in a mercuric chloride-amended broth culture $\left[10 \mu \mathrm{g} \mathrm{Hg}\left(\mathrm{as} \mathrm{HgCl}_{2}\right) \mathrm{ml}^{-1}\right.$ of B69A. Secondly, single colonies of B69A were detected within the clear zone of inhibition around discs impregnated with mercuric chloride. The adaptation-mutation test of Luria \& Delbrück (1943) was employed in order to demonstrate that the derivative strains resulted from a mutation event, rather than adaptation to growth in the presence of mercury. The mutation rate was $3.5 \times 10^{-7}$ mutational events per generation for strain B69A.

A representative mutant strain, designated B69AR1, was isolated and characterized. The degree of resistance to mercuric compounds was determined, using the disc diffusion test. Results indicated that the resistance of the mutant strain was between that observed for resistant parental strain B69 and the hypersensitive strain B69A (Table 1). MICs determined for strains $\mathrm{B} 69, \mathrm{~B} 69 \mathrm{~A}$, and B69AR1 were $25,0.25$, and $5.0 \mu \mathrm{g} \mathrm{Hg}\left(\mathrm{as} \mathrm{HgCl}_{2}\right) \mathrm{ml}^{-1}$, respectively. Resistance patterns obtained for some of the organomercurials followed those observed for inorganic mercury (Table 1). Thus, strain B69A was found to be hypersensitive to mercuric acetate and fluorescein mercuric acetate, whereas B69 and the mutant strain (i.e. B69AR1) were resistant and sensitive to these compounds, respectively. Strain B69A was sensitive to, and strains B69 and B69AR1 were resistant to $p$-hydroxymercuribenzoate.

Resistance to several antibiotics and various heavy metal salts was tested, in order to determine whether the mutation which renders B69AR1 sensitive to mercury also altered susceptibility to other antibacterial agents. No such alterations were detected, i.e. the previously reported resistance patterns (Olson et al., 1979) were observed for the mutant strains.

Mercury concentrations in the medium were monitored during growth of strain B69AR1 (Olson et al., 1979). Loss of mercury from the medium was not observed, even though a 10000fold increase in cell mass was detected after incubation for $30 \mathrm{~h}$. Thus, the partial gain of resistance in strain B69AR1 did not arise from volatilization of mercury.

\section{Mercury volatilization by transconjugant strains}

Volatilization rates of mercury (as $\mathrm{HgCl}_{2}$ ), were determined for strains $\mathrm{B} 69, \mathrm{~B} 69 \mathrm{~A}^{*}$ and B69AR 1*. Cultures, induced by overnight growth in broth amended with $1.0 \mu \mathrm{g} \mathrm{Hg} \mathrm{ml}^{-1}$, were diluted 1:100 into fresh medium containing $10 \mu \mathrm{g} \mathrm{Hg} \mathrm{ml}^{-1}$. Volatilization and growth kinetics were monitored as previously described (Olson et al., 1979). Loss of mercury from the growth media of the three tested strains and of an uninoculated control is illustrated in Fig. 1. Identical volatilization patterns were observed for the parental strain B69 and strain B69A*, with loss of $70 \%(\mathrm{w} / \mathrm{v})$ of added mercury occurring within $12 \mathrm{~h}$. A reduced rate of volatilization was observed for strain B69AR1*, with as much as $80 \%(\mathrm{w} / \mathrm{v})$ of the added mercury still present in the growth medium after $26 \mathrm{~h}$ of incubation. Identical bacterial growth patterns were demonstrated by the three strains, with a cell density of $5.0 \times 10^{9}$ cells ml-1 at the end of the exponential growth phase. 


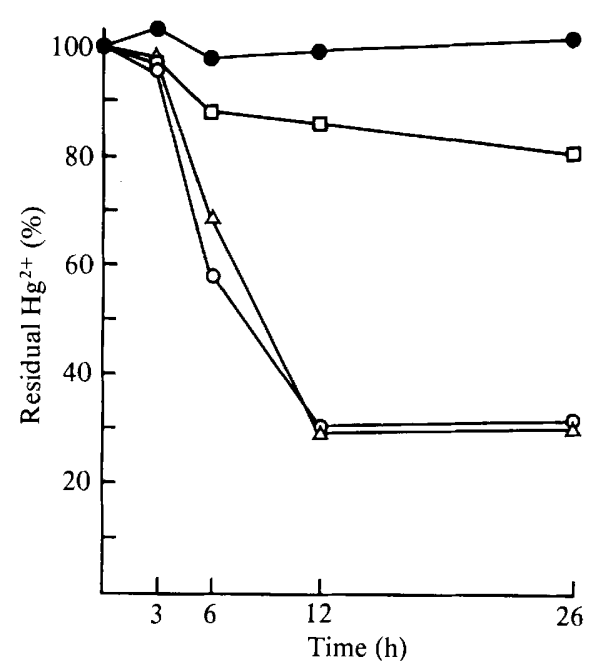

Fig. 1. Mercury volatilization by $P$. fluorescens B69, B69A* and B69AR1*. Loss of mercury from the growth medium was monitored as described in Methods. The percentage of the total mercury added (as $\mathrm{HgCl}_{2}$ ) remaining in the medium is given for strains: B69 $(O) ; \mathrm{B}^{\circ} \mathrm{A}^{*}(\triangle) ; \mathrm{B} 69 \mathrm{AR} 1^{*}(\square)$; and uninoculated control $(\mathrm{O})$

Table 2. Distribution of mercury (as $\mathrm{HgCl}_{2}$ ) in growth medium and cell mass after incubation for $26 h$

\begin{tabular}{|c|c|c|c|c|c|c|c|}
\hline \multirow[b]{3}{*}{ Strain } & \multicolumn{5}{|c|}{$\mathrm{Hg}$ conen $\dagger$} & \multirow{3}{*}{$\begin{array}{c}10^{-9} \times \text { no. } \\
\text { of cells } \mathrm{ml}^{-1} \S\end{array}$} & \multirow{3}{*}{$\begin{array}{l}10^{11} \times \mathbf{H g} \\
\text { per cell }(\mu \mathrm{g})\end{array}$} \\
\hline & \multirow{2}{*}{$\begin{array}{c}\text { Total } \\
\left(\mu \mathrm{g} \mathrm{ml}^{-1}\right)\end{array}$} & \multicolumn{2}{|c|}{ Supernatant } & \multicolumn{2}{|c|}{ Pellet } & & \\
\hline & & $\left(\mu \mathrm{g} \mathrm{ml}^{-1}\right)$ & $(\%) \ddagger$ & $\left(\mu \mathrm{g} \mathrm{ml}^{-1}\right)$ & $(\%)+$ & & \\
\hline B 69 & $3 \cdot 42$ & $3 \cdot 56$ & 100 & $0 \cdot 1$ & $2 \cdot 9$ & $6 \cdot 2$ & $1 \cdot 6$ \\
\hline B69A* & 3.49 & $3 \cdot 87$ & 100 & 0.06 & $1 \cdot 7$ & $3 \cdot 2$ & 1.9 \\
\hline B69AR 1* & $9 \cdot 00$ & $7 \cdot 84$ & $87 \cdot 1$ & $1 \cdot 32$ & $14 \cdot 7$ & $5 \cdot 6$ & $24 \cdot 0$ \\
\hline
\end{tabular}

$\uparrow$ Mercury was analysed as described in Methods.

$\$$ Percentage of total mercury.

$\S$ Cell counts were determined by spread-plating diluted samples on modified Yamada medium (Olson et al., 1979). Inoculated plates were incubated for $48 \mathrm{~h}$ at $25^{\circ} \mathrm{C}$.

\section{Association of mercury with cells}

The amounts of mercury associated with the cells of strains B69, B69A* and B69AR1* after $26 \mathrm{~h}$ of growth in $\mathrm{Hg}$ (as $\mathrm{HgCl}_{2}$ )-amended medium were determined (Table 2). Only negligible amounts of mercury were associated with the cells of strains B69 and B69A*. In contrast, $14.7 \%$ of the residual mercury was associated with the cells of strain B69AR1*. When the amount of mercury per viable cell was calculated, B69AR $1^{*}$ cells were found to be associated with at least ten times more mercury than $\mathrm{B} 69$ and $\mathrm{B} 69 \mathrm{~A}^{*}$ cells (Table 2 ). When a similar analysis was carried out with strain B69AR1, $15.5 \%$ of the total mercury, i.e. $0.89 \mu \mathrm{g} \mathrm{Hg} \mathrm{ml}^{-1}$ of the total of $5.69 \mu \mathrm{g} \mathrm{Hg} \mathrm{ml}{ }^{-1}$, was cell-associated (data not shown).

Cell-associated $\mathrm{Hg}$ was found exclusively in the cell envelope fraction, analysed after cellular disruption with a French Pressure Cell (Aminco 4-3396, Travenol Labs, Inc., Savage, Md., U.S.A.) and fractionation by ultracentrifugation at $120000 \mathrm{~g}$ for $20 \mathrm{~min}$. Washing the cell walls with fresh growth medium did not release any bound mercury, indicating a tight association of the $\mathrm{Hg}$ to the wall material. Bound mercury was released after overnight incubation with trypsin (Sigma) added to a final concentration of $1.2 \mu \mathrm{g} \mathrm{ml}^{-1}$. Loss of bound mercury was not detected when cell wall preparations were similarly incubated in the absence of trypsin. 


\section{DISCUSSION}

The conjugal transfer of mercury resistance from $P$. fluorescens B69 to its isogenic strain B69A confirms the identification of the $34 \mathrm{MDal}$ plasmid as a mercury-resistance plasmid. Resistance patterns to organomercurials (Table 1), indicate that the $34 \mathrm{MDal}$ plasmid is a 'narrow range' mercury-resistance plasmid, since it conferred resistance to $p$-hydroxymercuribenzoate and fluorescein mercuric acetate, but not volatilization of mercury from these compounds (Barkay, 1980). No other resistance to antibacterial agents was co-transferred with mercury resistance to the recipient strains, indicating no genetic linkage between this trait and the resistances observed for P. fluorescens B69 (Olson et al., 1979).

Mutants able to grow in the presence of an elevated concentration of mercury were selected when the hypersensitive strain B69A was exposed to $10 \mu \mathrm{g} \mathrm{Hg}\left(\right.$ as $\left.\mathrm{HgCl}_{2}\right) \mathrm{ml}^{-1}$. The mutation might have been masked by the higher level of resistance conferred by the mercury-resistance plasmid in the parental strain B69. Isolation of mutants, therefore, would not be achieved until the plasmid was eliminated. The resistance level demonstrated by strain B69AR1 [5.0 $\mu \mathrm{g} \mathrm{Hg}$ (as $\left.\mathrm{HgCl}_{2}\right) \mathrm{ml}^{-1}$ ] was in the range found for mercury-sensitive hospital bacterial isolates (Nakahara et al., 1977). However, no information is available for resistance levels of sensitive bacteria isolated from the aquatic environment.

Levels of mercury resistance demonstrated by strains B69, B69A and B69AR1 are similar to those reported for resistant, hypersensitive, and sensitive $E$. coli strains, respectively. On a genetic basis, hypersensitivity to mercury is attributed to an active merT gene in the absence of a functioning mer $A$ gene (Foster et al., 1979; Summers \& Kight-Olliff, 1980). If resistance in strain B69 resulted from a similar phenomenon, a functioning mer $T$ gene should be present in strain B69A, implying that either merT is not carried on the $34 \mathrm{MDal}$ plasmid, or that an additional merT gene is part of $P$. fluorescens B69 genome. Wang et al. (1978) reported a plasmiddetermined increased sensitivity to mercury, which they attributed to an active mer $T$ gene. Information presently available is not sufficient to draw conclusions as to the genetic origin of the hypersensitivity observed for strain B69A.

Strain B69AR1 phenotype appears to arise from an alteration in cell wall permeability to mercury. A reduced rate of volatilization was demonstrated by strain B69AR ${ }^{*}$, compared to strains B69 and B69A* (Fig. 1). The mercury-resistance plasmid was present in strain B69AR1*, judged by its physical presence in DNA preparations, this strain's full resistance to mercury, and the fact that it volatilized mercury (albeit at lower rates). Therefore, the only possible explanation for the decrease in the rate of mercury volatilization must lie in a reduced transport of this heavy metal from the growth medium to the cytoplasmic mercuric reductase.

Mercury-sensitive derivatives of hypersensitive $E$. coli strains were described by Foster \& Nakahara (1979), who ascribed this phenomenon to the inactivation of the permease gene, $\operatorname{mer} T$. Hypersensitive cells, containing an active $\operatorname{mer} T$, hyperbound mercury, compared to sensitive merT cells (Nakahara et al., 1979b). No such differences in binding of radioactive mercury were detected when the procedure described by Nakahara et al. $(1979 b)$ was performed with strains B69A and B69AR1. Both of the strains that were tested bound identical amounts of mercury, yielding similar binding rates (data not shown). However, B69ARI and B69AR1* cultures at the late-exponential phase of growth were consistently found to be associated with greater amounts of mercury than B69 or B69A*. We therefore suggest that the impaired step in the transport of mercury in the mutant strain is not the mer $T$-mediated function, but, more likely, another, as yet unidentified part of the transport system. Alternatively, the possibility remains that mercury transport in $P$. fluorescens B69 differs from the system studied in $E$. coli.

In summary, $P$. fluorescens B69ARl appears to possess a mutation involved in mediating reduced mercury transport through the cell envelope. Since this mutation does not seem to affect the mercuric permease gene, $\operatorname{mer} T$, it indicates that either additional components of the mercury transport system exist or else that $\boldsymbol{P}$. fluorescens $\mathrm{B} 69$ mercury transport system differs from the $E$. coli system. The results of this study suggest the complex role of mercury transport in bacterial resistance to mercurials. 
We thank Dr David Popkin for his assistance with the conjugation experiments. Our grateful appreciation is expressed to Mrs Gwen Brown for her expert assistance in preparing the manuscript. This work was supported by the U.S. National Science Foundation Grant no. DEB 77-14646 and National Oceanic and Atmospheric Administration Sea Grant 04-8-MOI-71.

\section{REFERENCES}

Austin, B., Allen, D. A., Mills, A. L. \& Colwell, R. R. (1977). Numerical taxonomy of heavy metaltolerant bacteria isolated from an estuary. Canadian Journal of Microbiology 23, 1433-1447.

BARKAY, T. (1980). The role of plasmids in mercury resistance mechanisms of aquatic bacteria. Ph.D thesis, University of Maryland, U.S.A.

Bauer, A. W., Kirby, W. M. M., Sherris, J. C. \& TurcK, M. (1966). Antibiotic susceptibility testing by a standardized single disk method. American Journal of Clinical Pathology 45, 493-496.

Foster, T. J. \& NaKaHaRa, H. (1979). Deletions in the r-determinant mer region of plasmid R 100-1 selected for loss of mercury hypersensitivity. Journal of Bacteriology 140, 301-305.

Foster, T. J., Nakahara, H., Weiss, A. A. \& Silver, S. (1979). Transposon A-generated mutations in the mercuric resistance gene of plasmid R 100-1. Journal of Bacteriology 140, 167-181.

Luria, S. E. \& DelbrüCK, M. (1943). Mutations of bacteria from virus sensitivity to virus resistance. Genetics 28, 491-511.

Nakahara, H., Ishikawa, T., SaraI, Y., Kondo, I., Kozukue, H. \& Silver, S. (1977). Linkage of mercury, cadmium and arsenate and drug resistance in clinical isolates of Pseudomonas aeruginosa. Applied and Environmental Microbiology 33, 975-976.

Nakahara, H., Kinscherf, T. G., Silver, S., Miki, T., Easton, A. M. \& Rownd, R. H. (1979a). Gene copy number effects in the mer operon of plasmid NR1. Journal of Bacteriology 138, 284-287.

NaKahara, H., Silver, S., Miki, T. \& Rownd, R. H. $\left(1979 b\right.$ ). Hypersensitivity to $\mathrm{Hg}^{2+}$ and hyperbinding activity associated with cloned fragments of the mercurial resistance operon of plasmid NR1. Journal of Bacteriology 140, 161-166.

Olson, B. H., Barkay, T. \& Colwell, R. R. (1979). Role of plasmids in mercury transformation by bacteria isolated from the aquatic environment. Applied and Environmental Microbiology 38, 478-485.

PaN-Hou, H. S. K. \& ImURA, N. (1981). Role of hydrogen sulfide in mercury resistance determined by plasmid of Clostridium cochlearium T-2. Archives of Microbiology 129, 49-52.

Pan-Hou, H. S., Nishimoto, M. \& ImuRa, N. (1981). Possible role of membrane proteins in mercury resistance of Enterobacter aerogenes. Archives of Microbiology 130, 93-95.

SchotTel, J. L. (1978). The mercuric and organomercurial detoxifying enzymes from a plasmid-bearing strain of Escherichia coli. Journal of Biological Chemistry 253, 4341-4349.

Summers, A. O. \& Kight.-Olliff, L. (1980). Tn1 generated mutants in the mercuric ion reductase of the inc P plasmid, R702. Molecular and General Genetics 180, 91-97.

Summers, A. O. \& Silver, S. (1978). Microbial transformations of metals. Annual Review of Microbiology 32, 637-672.

Wang, P. Y., Relf, J., Palchaudhuri, S. \& IYer, V. N. (1978). Plasmid conferring increased sensitivity to mercuric chloride found in some laboratory strains of Escherichia coli K-12. Journal of Bacteriology 133, 1042-1043.

Weiss, A. A., Schottel, J. L., Clark, D. L., Beller, R. G. \& Silver, S. (1978). Mercury and organomercurial resistance with enteric, Staphylococcal, and Pseudomonad plasmids. In Microbiology-1978, pp. 121-124. Edited by D. Schlessinger. Washington, D.C.: American Society for Microbiology.

Work, E. (1971). Cell Walls. Methods in Microbiology 5A, 361-418.

Yamada, M. \& Tonomura, K. (1972). Formation of methylmercury compounds from inorganic mercury by Clostridium cochlearium. Journal of Fermentation Technology 50, 159-166. 